Relations industrielles

Industrial Relations

\title{
New Concepts of Working Conditions
}

\section{James O'Connell-Maher}

Volume 2, numéro 1, 1946

URI : https://id.erudit.org/iderudit/1023676ar

DOI : https://doi.org/10.7202/1023676ar

Aller au sommaire du numéro

Éditeur(s)

Département des relations industrielles de l'Université Laval

ISSN

0034-379X (imprimé)

1703-8138 (numérique)

Découvrir la revue

Citer cet article

O'Connell-Maher, J. (1946). New Concepts of Working Conditions. Relations industrielles / Industrial Relations, 2(1), 4-4. https://doi.org/10.7202/1023676ar

Tous droits réservés @ C Département des relations industrielles de l’Université Laval, 1946
Ce document est protégé par la loi sur le droit d'auteur. L’utilisation des services d'Érudit (y compris la reproduction) est assujettie à sa politique d'utilisation que vous pouvez consulter en ligne.

https://apropos.erudit.org/fr/usagers/politique-dutilisation/ 


\section{NEW CONCEPTS OF WORKING CONDITIONS}

The history of mankind shows that wars, though unfailingly disastrous and cruel, have always contributed directly or indirectly to the progress of civilization in general ; the universal clash which has just come to an end is no exception to that rule, and therefore, we are beginning to perceive its effects on working conditions.

From 1939 to 1945 the industries of the democracies were strained nearly to the breaking point ; the task to be done was to produce more and better weapons so that our three armed forces might achieve final victory. In order to increase production, industry called upon the undivided co-operation of its engineers, and for the sam.e reason governments also requested and obtained the required co-operation of labour, both organized or not.

However it was necessary to have the workers work under conditions that would be consistent with the efficiency required of them; and experience has proved in the course of this war, that the only means of achieving such an end was to raise working conditions to a level that would admit of a maximum physical and mental effort. The ensuing realizations are quite interesting and we already notice that they are being introduced permanently in the course of this reconversion period.

At the plant, a worker exerts himself both mentally and physically ; since many years, organized labour and the governments have taken the steps required to provide physical rests for workers by limiting the duration of labour and by granting weekly or (of late) annual holidays. Nowadays it is universally recognized that an employee needs peace of mind : such serenity can only be obtained through the practical application of new concepts of social security as to permanency of employment and of an ever improving system of vocational guidance.

Here are a few problems in which the heads of our governments, industries and labour movements are actually concerned. Their solution will undoubtedly benefit both industry and labour, as well as the nation as a whole.

$1^{\circ}$ Medical exumination prior to employment:-This highly important question will be studied by the International Labour Office in the course of its conference at Montreal in September and October. Needless to say that physical fitness for a given task, specially at the outset of a career, is of prime importance not only to the individual but aiso to his employer. The degree of adaptation of an employee directly influences his efficiency, his productivity, and even the duration of his employment at a given task.

$\mathscr{2}^{\circ}$ Vocational guidance : - In some measure, physical adaptation has an effect upon vocational guidance : therefore, it-is only when medical examination prior to employment becomes an accomplished fact that the system will be improved. However, notwithstanding the foregoing remark, determining mental fitness for a given task is extremely important. That is why educators, right-thinking industrialists and organized labour increasingly favour vocational guidance not only within the family but also in schools and during technical and post-graduate studies. One must be well adapted for his work to succeed and progress in it, and adaptation becomes impossible if one merely relies on circumstances to determine the ranner in which he will earn his living.

$3^{\circ}$ Permanency of employment : - Some time ago, in order to cope with the consequences of unemployment, most governments adopted the measures required, by carrying out such plans as State insurance or assistance ; the measures in question were only remedies.

The new formula advocated by organized labour, chiefly in the United States, is the guarantee of being employed, in industry, during a minimum number of days per year ; this system could be called a preventive measure against unemployment.

The end to be achieved is obviously an excellent one, but on the other hand the whole system of permanency of employment is dependent on the very economic activity of the nation, and, in short, could eliminate neither unemployment insurance nor assistance.

The fact of being absolutely sure of having work tor a certain period of time gives peace of mind to an employee, since it guarantees security for him.

$4^{\circ}$ Fatigue :-During the war, the physical and mental fatigie of soldiers formed the subject of serious medical research; the Arrerican General Staff was recently handed a report determining exactly the maximum number of days during which a soldier could withstand active service under fire or elsewhere. Industry -- as this report advises - will surely undertake similar investigations and draw accurate medical conclusions as to the maximum duration of labour during which productive activity ean be n'aintained at its highest level:

So far, the method used consisted in the proportional reduction of working hours as compared with industrial activity in general, the deve'opment of a plant in particular or the local labour market ; the medical proof of the maximum duration of labour has been established in a few exceptional cases only. As concerns rest periods, standards have already been prescriked, but in this instance medical proof is lacking once more.

It is thus an objective to be achieved. Several employers in the Province of Quebec are in favour of this plan ; it is only a question of promoting the plan and securing the co-operation of all right-thinking parties concerned.

These improverrents are not the manifestation of ever higher objectives to be obtained by the working class : they are merely the formulation of modern systems which will enable capital to increase production by making better use of labour ; which will enable workers to make a better contribution to production while earning more and preserving security, so dear to all, and which will improve the nation's standard of living and further the progress of eivilization.

J AMEs O'Connell-Maher. 